\title{
Perubahan Morfologi Muara Sungai di Pesisir Kota Semarang dalam Penanggulangan Banjir dan Rob
}

\author{
Heryoso Setiyono*, Muhammad Helmi, Indra Budi Prasetyawan, Muh Yusuf dan Azis Rifai \\ Departemen Oseanografi, Fakultas Perikanan dan Ilmu Kelautan, \\ Universitas Diponegoro, Semarang 50275 \\ "E-mail: heryoso.setiyono@live.undip.ac.id
}

\begin{abstract}
A study of rivermouth in the coastal of Semarang City for reduction rob flood hazard was investigated. The purpose of this study is to identify the shape, size, pattern of rivermouth changes and the factors of the sea that affect it that has the potential to cause rob disasters so that can be taken a preventive action. The research location is along the coast in the administrative area of Semarang City Government and the area affected by rob flood. The method used is cartometric analysis from various maps. The results show that the condition of the rivermouth is much influenced by the conditions along the river passing through certain land use areas. Human factors are very influential on the changes and layout of the river mouth. River and river mouth conditions are grouped under natural conditions, castration, deflection, normalization and some combinations. Rivermouth which still natural are included Tenggang, Seringin and Pentol. The rivermouth that experienced deflection are the rivermouth of Banger and Kanal Banjir Timur (KBT). The natural and normalized rivermouth is Kali Babon. The rivermouth that is still natural but experienced spoofing is Kali Semarang.The rivermouth that normalized is Kanal Banjir Barat (KBB).
\end{abstract}

Keywords: river mouth, rob flood, Semarang

\begin{abstract}
ABSTRAK
Penelitian tentang studi muara sungai di pesisir Kota Semarang untuk mereduksi bencana rob telah dilakukan. Tujuan penelitian adalah untuk mengidentifikasi perubahan bentuk, ukuran, pola muara-muara sungai serta faktor-faktor fisik lainnya dari laut terkait dengan penanggulangan banjir dan rob sehingga dapat diambil langkah-langkah pencegahannya. Lokasi penelitian di sepanjang pesisir wilayah Kota Semarang antara Kanal Banjir Barat (KBB) dan Kali Babon. Metode yang digunakan adalah analisis citra satelit dan peta rupa bumi serta dilengkapi dengan tinjauan lapangan. Hasil penelitian menunjukkan bahwa terjadi perubahan bentuk muara sungai. Faktor manusia sangat berpengaruh terhadap perubahan dan tata letak muara sungai. Kondisi sungai dan muara sungai dikelompokkan atas kondisi alamiah, penyodetan, pembelokan, normalisasi dan beberapa kombinasinya. Muara sungai yang masih alamiah antara lain: Tenggang dan Sringin. Muara sungai yang mengalami pembelokan antara lain adalah Sungai Banger dan Kanal Banjir Timur (KBT). Muara sungai yang masih alamiah dan dinormalisasi yaitu Kali Babon. Muara sungai yang alamiah tetapi mengalami penyodetan yaitu Kali Semarang. Muara sungai yang mengalami normalisasi yaitu Kanal Banjir Barat (KBB). Penanganan serta pengendalian banjir dan rob secara terpadu mengurangi dampak penggenangan secara efektif.
\end{abstract}

Kata kunci: banjir rob, muara sungai, Semarang

\section{PENDAHULUAN}

Kota Semarang merupakan salah satu daerah yang sangat rawan terjadinya bencana banjir dan rob di kawasan pesisir. Banjir pesisir merupakan salah satu permasalahan di Kota Semarang bagian bawah sehingga memerlukan beberapa kajian, salah satu di antaranya adalah keadaan muara sungai. Kondisi geografi seperti topografi, geologi, penggunaan lahan, dan pertambahan penduduk merupakan faktor utama pemicu terjadinya banjir dan rob yang makin parah.

Muara sungai adalah pertemuan antara sungai dan laut, di mana antara aliran air sungai yang datang dari hulu bertemu dengan proses-proses berasal dari laut (pasang surut, gelombang, dan arus) yang 
berlangsung di pantai. Muara sungai berperan sebagai pintu keluar (outlet) bagi aliran sungai yang berasal dari darat dan bagian hulu, sekaligus pada waktu tertentu berperan sebagai pintu masuk (inlet) bagi air laut ketika terjadi pasang naik. Selain itu, keberadaan rawa maupun laguna di pesisir sangat membantu sebagai tempat penampungan air dalam sistem sirkulasi air di kawasan pesisir

Banjir dan rob di Kota Semarang termasuk masalah yang hingga ini masih belum terpecahkan. Permasalahan banjir yang disebabkan oleh banjir dan rob tersebut telah mencapai kondisi yang memprihatinkan, karena secara langsung maupun tidak langsung menyebabkan terhambatnya berbagai kegiatan ekonomi dan sosial.

Penanganan banjir dan rob merupakan kegiatan satu paket yang dilakukan secara terpadu oleh instansi terkait. Penanganan banjir di Kota Semarang sudah dilakukan sejak tahun 2007 melalui Master Plan Rencana Induk Drainase Kota Semarang, bahkan sejak jaman Hindia Belanda sudah dilakukan pembuatan Kanal Banjir Barat (KBB) dan Kanal Banjir Timur (KBT). KBT sebagai salah satu kanal pengendali banjir di Kota Semarang di bagian timur belakangan ini tidak dapat berfungsi secara optimal sehingga masih menyebabkan banjir dan rob. Pada tahun 2016 telah dilakukan Desain Dasar Tanggul Laut KBT dan Kali Babon. Selanjutnya pada tahun 2017 dilakukan penanganan banjir dan rob secara terpadu dengan nama Pengendalian Banjir dan Rob Paket I dan Paket II oleh Kementerian PUPR.

Tujuan penelitian ini adalah untuk mengidentifikasi perubahan morfologi muara sungai antara KBB dan Kali Babon serta faktor-faktor fisik lainnya dari terkait dengan timbulnya bencana banjir dan rob di pesisir Kota Semarang sehingga dapat diambil langkah-langkah pencegahannya.

\section{METODE PENELITIAN}

\subsection{Lokasi Penelitian}

Lokasi penelitian adalah muara sungai di antara KBB di bagian barat dan Kali Babon di bagian timur dengan koordinat geografi antara $110^{\circ} 24^{\prime} 30^{\prime \prime}$ - $110^{\circ} 27^{\prime} 32^{\prime \prime}$ Bujur Timur dan $6^{\circ} 56^{\prime} 60^{\prime \prime}-6^{\circ} 57^{\prime} 00^{\prime \prime}$ Lintang Selatan (Gambar 1).

\subsection{Data Penelitian}

Data penelitian yang digunakan terdiri dari beberapa macam peta untuk wilayah Kota Semarang yaitu: a).Peta rupabumi tahun 2000 skala 1:25.000 Lembar Beji dan Lembar Semarang, b). Peta sungai/ daerah aliran sungai wilayah Kota Semarang, c).Citra foto udara, d) peta hidrogeologi Indonesia Skala 1:250.000 Lembar Semarang, dan e). data debit sungai dan kejadian banjir dari Dinas PSDA Jawa Tengah.

\subsection{Analisa Data}

Analisa data dilakukan menggunakan metode kartometri pada citra satelit dan peta rupa bumi yang meliputi bentuk, pola, dan ukuran sungai. Pengamatan langsung di lapangan dilakukan untuk memperkuat analisa data. Berdasarkan analisa kartometrik dapat dilakukan inventarisasi dan identifikasi karakteristik muara sungai dengan sistem aliran sungainya. Selain itu, konfigurasi sungai dan muara sungai dianalisis korelasinya dengan peta-peta lainnya, seperti peta penggunaan lahan dan peta kerentanan banjir, untuk mengidentifikasi daerah-daerah yang rawan terhadap banjir dan rob. Data kondisi curah hujan dan data kejadian banjir digunakan untuk mendukung analisa karakteristik muara sungai. 


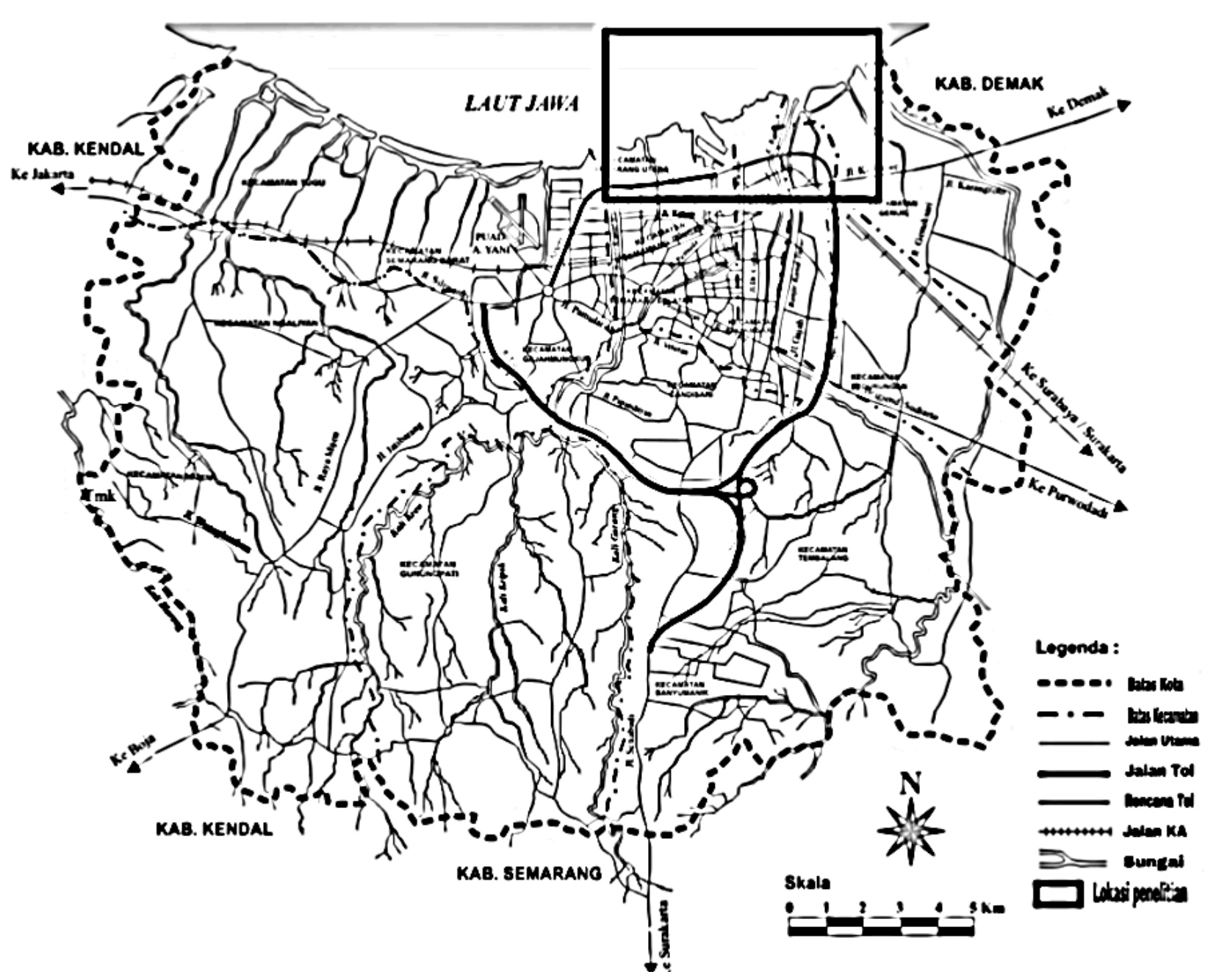

Gambar 1. Lokasi penelitian

\section{HASIL DAN PEMBAHASAN}

\subsection{Kondisi muara sungai di Kota Semarang}

Secara garis besar sungai-sungai utama yang bermuara di pesisir Kota Semarang dikelompokkan menjadi tiga daerah aliran sungai (DAS), yaitu Bringin, Garang, dan Mundu. Sementara DAS yang paling berperan menimbulkan banjir, selain dalam hal ukuran luasan maupun banyaknya aliran adalah DAS Garang dan DAS Mundu. Kedua DAS tersebut berhulu di Gunung Ungaran. DAS Garang merupakan hulu dari KBB dan Kali Semarang, sedangkan DAS Mundu merupakan hulu dari Kali Banger, KBT, Kali Tenggang, Kali Sringin, dan Kali Babon.

Di sepanjang pesisir Kota Semarang terdapat 15 muara sungai. Hasil identifikasi muara sungai di wilayah Kota Semarang yang berada pada zona yang sering terkena banjir pesisir, yaitu terletak di antara KBB di bagian barat dan Kali Babon di bagian timur. Di antara kedua sungai tersebut terdapat sedikitnya delapan buah muara sungai. Sebagian besar muara sungai tersebut berada di wilayah Kecamatan Semarang Utara sebanyak tiga buah dan lainnya di wilayah Kecamatan Genuk sebanyak lima buah. Delapan buah muara sungai tersebut dengan berbagai kondisi: a. masih alamiah, b. 
mengalami normalisasi c. mengalami pembelokan, d. mengalami penyodetan, e. buatan (Tabel 1).

KBB semula bernama Kali Semarang Barat merupakan kelanjutan Kali Garang di bagian hulu. Berdasarkan data debit maksimum selama periode 1998-2007 KBB memiliki rata-rata sebesar 406,00 $\mathrm{m}^{3} /$ detik. Berdasarkan rata-rata curah hujan tahunan di kawasan hulu (Gunung Ungaran) berkisar antara 4000-4500 mm. Kejadian banjir besar tahun 1990 yang ditimbulkan oleh KBB menunjukkan kondisi debit 1.103,73 $\mathrm{m}^{3} /$ detik dan rata-rata curah hujan di DAS Garang sebesar 171,60 mm (Setyowati dan Suharini, 2011).

KBB (Gambar 2) dinormalisasi untuk memperlancar aliran sungai yang bersumber dari gabungan Kali Garang dan kali-kali lain yang lebih kecil di daerah aliran sungai (DAS) Garang. KBB merupakan hasil sodetan dan pelurusan dari Kali Semarang yang dibuat pada masa kolonial Hindia Belanda. Diduga hal ini berkaitan untuk mengurangi beban aliran Kali Semarang yang rawan menimbulkan bencana banjir. Kali Semarang sekitar 2,5 km menjelang garis pantai disodet ke arah utara sehingga membentuk cabang dengan muaranya berada di Pelabuhan Tanjung Mas. Kali Semarang sendiri ketika menuju ke laut memiliki arah ke barat laut. Kali hasil penyodetan tersebut dinamakan Kalibaru Timur. Penyodetan tersebut dilakukan untuk memperpendek jarak aliran ke arah laut.

Kali Banger dan KBT semula berupa dua batang sungai terpisah yang lurus ke utara. Oleh karena di bagian muara kedua sungai tersebut dibangun tempat pelelangan ikan (TPI) Tambakmulyo (Kecamatan Semarang Utara), maka kedua sungai tersebut berjarak sekitar 1,5 km dari garis pantai dibelokkan ke arah timur laut dan berhimpitan dengan muara sungai Tenggang di Kelurahan Terboyo Kulon (Kecamatan Genuk) (Gambar 3).

Kali Tenggang diperpanjang ke arah utara dengan dibuat pematang baru menembus kawasan rawa sampai berakhir di perpotongan dengan Jalan Arteri Utara. Kali Sringin tidak mengalami perubahan, tetapi bagian tepi sungai ditinggikan dengan dibeton. Kali Babon mengalami normalisasi dengan bentuk penurapan dan pembuatan tanggul sungai di sepanjang sungai mulai dari kawasan permukiman Kelurahan Karangroto sampai ke muara sungai.

\subsection{Banjir, rob, dan penurunan daratan di Kota Semarang}

Peristiwa banjir dan rob di kawasan pesisir kota Semarang merupakan dua hal yang berbeda, tetapi kedua peristiwa tersebut dapat muncul secara bersama-sama. Banjir disebabkan curah hujan, sementara rob disebabkan gerakan air laut yang bergerak naik sampai jauh ke arah daratan.

Selama musim penghujan di wilayah pesisir kota Semarang hampir dipastikan terjadi banjir. Banjir tahun 2017 dan 2018 yang terjadi sekitar Desember-April serta rob sekitar Mei. Banjir besar bersumber dari aliran Kali Garang sebagai hulu dari KBB pernah terjadi beberapa kali, antar lain tahun 1963, 1990, 2000, 2002, dan 2008. Kejadian terbesar terjadi pada tanggal 26 Januari 1990 berupa meluapnya Kali Garang dan jebolnya tanggul KBB dengan menelan korban jiwa sebanyak 47 meninggal, 25 rumah hancur, 125 rumah tenggelam dan menimbulkan luas genangan seluas 1.670 ha (Setyowati dan Suharini, 2011). Banjir besar tahun 2017 dan 2018 yang terjadi sekitar Desember-April dan rob sekitar bulan Mei menyebabkan kemacetan lalu lintas luar biasa terutama di Jalan Kaligawe (Kecamatan Genuk) yang menghubungkan Semarang dengan kota-kota lain di sebelah timur seperti Demak, Kudus, Jepara, Surabaya,dll. Akibat kejadian tersebut masyarakat dirugikan secara ekonomi mengingat di sepanjang Jalan Kaligawe terdapat kawasan industri.

Peristiwa rob di pesisir Kota Semarang sudah terjadi sejak tahun 1970-an, dan semakin bertambah parah baik dari segi luasan maupun waktu (durasi) genangannya (Susanto, 2017). Cakupan luasan wilayah terluas yang terkena dampak banjir dan rob yaitu di Kecamatan Genuk (meliputi Kelurahan: Trimulyo, Terboyo Wetan, Terboyo Kulon) dan Kecamatan Semarang Utara (Kelurahan Tanjung Mas). Di Kelurahan Tanjung Mas ketinggian rob di RW 1-11 bervariasi antara 10-50 cm dan RW 12-16 lebih dari $50 \mathrm{~cm}$ (Putra dan Handayani, 2013). Menurut Pratiwi et al. (2010) luas genangan banjir tinggi mencapai 7.815 ha yang tersebar di 12 kecamatan di Kota Semarang, sedangkan luas genangan rob maksimum mencapai 4.934 ha 
yang tersebar di delapan kecamatan pesisir Kota Semarang. Berdasarkan tingkat kepadatan permukiman yang paling luas berdampak terhadap kehidupan manusia adalah di Tanjung Mas. Di Kecamatan Genuk sebagian besar wilayahnya ditempati kawasan industri dan sebagian permukiman penduduk di bagian pesisir yang berhadapan dengan rawa dan tambak.

Di kawasan pesisir Kota Semarang selain sering dilanda banjir dan rob, juga terjadi peristiwa penurunan daratan (land subsidence) sehingga kombinasi ketiga hal tersebut memperparah permasalahan lingkungan. Selama ini kawasan di pesisir Kota Semarang telah mengalami penurunan tanah (land subsidence) dengan laju di daerah pantai dengan angka penurunan antara 1,0-9,0 cm/tahun (Kahar et al., 2010).

Permasalahan lain yang dihadapi pesisir Kota Semarang adalah dinamika perubahan garis pantai. Menurut Sardiyatmo et al. (2013) sepanjang tahun 1908-1937 garis pantai Kota Semarang mengalami akresi, dalam periode 1937-1972 garis pantai mengalami abrasi, dan periode 1972-1992 garis pantai mengalami akresi. Berdasarkan tiga lokasi sampling yang berbeda, bagian yang mengalami proses akresi yang paling jauh yaitu di sepanjang lintasan yang berujung di lokasi pelabuhan Tanjung Emas, yaitu sejauh $945 \mathrm{~m}$.

\subsection{Pembahasan}

Penanganan banjir sudah dimulai sejak tahun 2007, yaitu dibuat Rencana Induk Drainase Kota Semarang (Tabel 2) yang menjadi panduan jalan penanganan masalah-masalah yang berkaitan dengan banjir. Kegiatan yang ditangani yaitu sungai sebagai satu kesatuan DAS dari bagian hulu sampai hilir. Secara tidak langsung penanganan banjir tersebut sekaligus penanganan rob. Prioritas penanganan ditujukan terutama berkaitan badan sungai, termasuk di dalamnya muara sungai yaitu antara lain pengerukan dasar sungai, pembuatan tanggul sungai, pelurusan atau penyodetan sungai, penanganan muara sungai (pelebaran, pengerukan, pemindahan, normalisasi).

Pada tahun 2017 dilaksanakan pengendalian banjir dan rob sebagai satu kesatuan penanganan oleh pemerintah pusat (Kementerian Pekerjaan Umum dan Perumahan Rakyat (PUPR)), terutama untuk kawasan Kota Semarang bagian timur dengan nama Pengendalian Banjir dan Rob. Hal tersebut berkaitan dengan kejadian banjir dan rob yang parah pada tahun-tahun sebelumnya.

Dalam penanganan KBB yang merupakan bentuk kanal dan sodetan dari Sungai Semarang dengan nama Integrated Water Resources and Flood Management Project for Semarang meliputi kegiatan normalisasi KBB, perbaikan drainase kota, dan pembangunan Waduk Jatibarang sebagai satu kesatuan daerah aliran sungai. Tujuan utama dari proyek tersebut salah satunya mengurangi dampak banjir dan rob di kawasan dataran rendah pesisir Kota Semarang. KBB berfungsi mengendalikan kelebihan debit aliran Kali Garang dan mengalihkannya agar tidak semua aliran tersebut masuk ke Kali Semarang.

Menurut Wahyudi (2010) dalam perbandingan penanganan banjir rob di Perancis dan Belanda dengan Semarang perlunya penanganan dengan menggunakan sistem polder. Sistem polder yaitu cara penanganan banjir dengan bangunan fisik yang meliputi sistem drainase, kolam retensi, dan tanggul yang mengelilingi suatu kawasan serta dilengkapi dengan pompa dan pintu air. Disebutkan Polder Kali Banger memiliki daerah tangkapan 675 Ha yang meliputi sembilan kelurahan di Kecamatan Semarang Utara. Pengendalian banjir dilakukan dengan mengandalkan stasiun pompa. Elevasi air dalam kolam polder dikendalikan pada kedalaman -2 m di bawah MSL (mean sea level).

Hermono et al. (2012) dalam kaitannya pengendalian banjir dan rob di Kota Semarang menyimpulkan hal tersebut dapat diatasi dengan pembuatan dam lepas pantai dengan kombinasi polder dan tanggul laut. Keuntungan berikutnya area yang terbentuk di dalam dam lepas pantai dimanfaatkan untuk reklamasi lahan. Berdasarkan perhitungan pembiayaan proyek tersebut akan menggunakan dana yang sangat besar.

Muara sungai KBB, Kalibaru, Banger, KBT, dan Babon dipertahankan terbuka langsung dengan laut, sedangkan muara sungai Semarang, Tenggang, dan Sringin dibangun pintu pengendali banjir. Pada muara sungai yang terbuka langsung dengan laut dilakukan pelebaran dan pendalaman tubuh sungai. Sedangkan muara sungai yang dilengkapi pintu pengendali dilengkapi kolam retensi. Secara teknis muara sungai yang 
dilengkapi pintu pengendali bentuknya mirip sistem polder di mana kelebihan air (banjir) yang tertahan di pintu pengendali dibuang ke laut dengan menggunakan pompa.

Tabel 1. Keadaan muara sungai di pesisir Kota Semarang bagian timur

\begin{tabular}{|l|l|l|l|l|}
\hline No. & Muara sungai & Lokasi kecamatan & $\begin{array}{c}\text { Keadaan sungai dan muara } \\
\text { sungai }\end{array}$ & \multicolumn{1}{|c|}{$\begin{array}{l}\text { Keadaan jalur lintasan } \\
\text { sungai }\end{array}$} \\
\hline 1 & KBB & Semarang Utara & Normalisasi & Permukiman padat \\
\hline 2 & Semarang & Semarang Utara & alamiah & Permukiman padat \\
\hline 3 & Kalibaru Timur & Semarang Utara & $\begin{array}{l}\text { Hasil penyodetan Sungai } \\
\text { Semarang }\end{array}$ & Permukiman padat \\
\hline 4 & Banger & Genuk & Pembelokan, normalisasi & Permukiman padat \\
\hline 5 & KBT & Genuk & Pembelokan, normalisasi & Permukiman padat \\
\hline 6 & Tenggang & Genuk & Normalisasi & $\begin{array}{l}\text { Kawasan industri, rawa, } \\
\text { tambak }\end{array}$ \\
\hline 7 & Sringin & Genuk & Normalisasi & $\begin{array}{l}\text { Kawasan industri, rawa, } \\
\text { tambak }\end{array}$ \\
\hline 8 & Babon & Genuk & Normalisasi & $\begin{array}{l}\text { Kawasan industri, rawa, } \\
\text { tambak }\end{array}$ \\
\hline
\end{tabular}

\section{KESIMPULAN}

Bagian pesisir Kota Semarang merupakan daerah paling rawan terkena banjir, baik banjir yang berasal dari air kiriman dari hulu, maupun rob (banjir pasang air laut), terutama bagian pesisir dengan topografi yang ralatif datar dan lebih rendah dari pasang tertinggi. Daerah rawan banjir tersebut terutama terletak di Kota Semarang bagian timur.

Muara sungai sebagai bagian kesatuan sungai merupakan salah satu sistem pengendalian banjir dan rob. Muara sungai di pesisir Kota Semarang telah mengalami perubahan dalam bentuk penyodetan, pembelokan dan normalisasi. Selain itu sebagian sungai masih dengan muara sungai aslinya, terutama di Kecamatan Genuk, yaitu yang belum atau masih ditangani dalam proyek pengendalian banjir dan rob.

Perawatan muara sungai merupakan bagian penting dalam penanggulangan dampak bencana banjir dan rob di pesisir Kota Semarang. Selain itu penanganan melalui upaya-upaya lain, seperti perbaikan drainase, pembuatan polder, kolam retensi, tanggul laut, dan pengadaan pompa menjadi bagian tidak terpisahkan dengan penanganan muara sungai dalam penanggulangan banjir dan rob.

\section{REFERENSI}

Budinetro, H.S., Sri Rahayu, T.A. Praja, A.Taufik, dan D. Junarsa. 2012. Strategi Pengendalian Banjir Kota Semarang. J. Sumber Daya Air 8 (2): 141-156

Kahar, S., Purwanto, dan W.K. Hidayat. 2010. Dampak Penurunan Tanah dan Kenaikan Muka Laut terhadap Luas Genangan Rob Di Semarang. J. Presipitasi 7 (2): 83-91

Pratiwi, R.D., A.L. Nugraha, dan Haniah. 2016. Pemetaan Multi Bencana Kota Semarang. J. Geodesi Undip Oktober 2016:1-10 
Putra, A.D. dan W. Handayani. 2013. Kajian Bentuk Adaptasi Terhadap Banjir dan Rob Berdasarkan Karakteristik Wilayah dan Aktivitas Di Kelurahan Tanjung Mas. J. Teknik PWK 2(3):1-11. http://ejournal-sl.undip.ac.id/index.php/pwk

Sardiyatmo, Supriharyono, dan A. Hartoko. 2013. Dampak Dinamika Garis Pantai Menggunakan Citra Satelit Multi Temporal Pantai Semarang Provinsi Jawa Tengah. J. Saintek Perikanan 8(2):33-37. https://doi.org/10.14710/ijfst.8.2.33-37

Setyowati, D.L. dan E. Suharini. 2011. DAS Garang Hulu: tata air, erosi, dan konservasi. Widya Karya, Semarang. 91 hal

Susanto, A. 2017. Strategi Peningkatan Resiliensi Masyarakat Pesisir terhadap Tekanan Sosio-Ekologis (Studi Kasus Pesisir Kota Semarang). J. Matematika, Sains, dan Teknologi 18(1):11-27

Wahyudi, S.I. 2010. Perbandingan Penanganan Banjir Rob di La Briere (Perancis), Rotterdam (Belanda), dan Perspektif di Semarang (Indonesia). Riptek 4(11):29-35

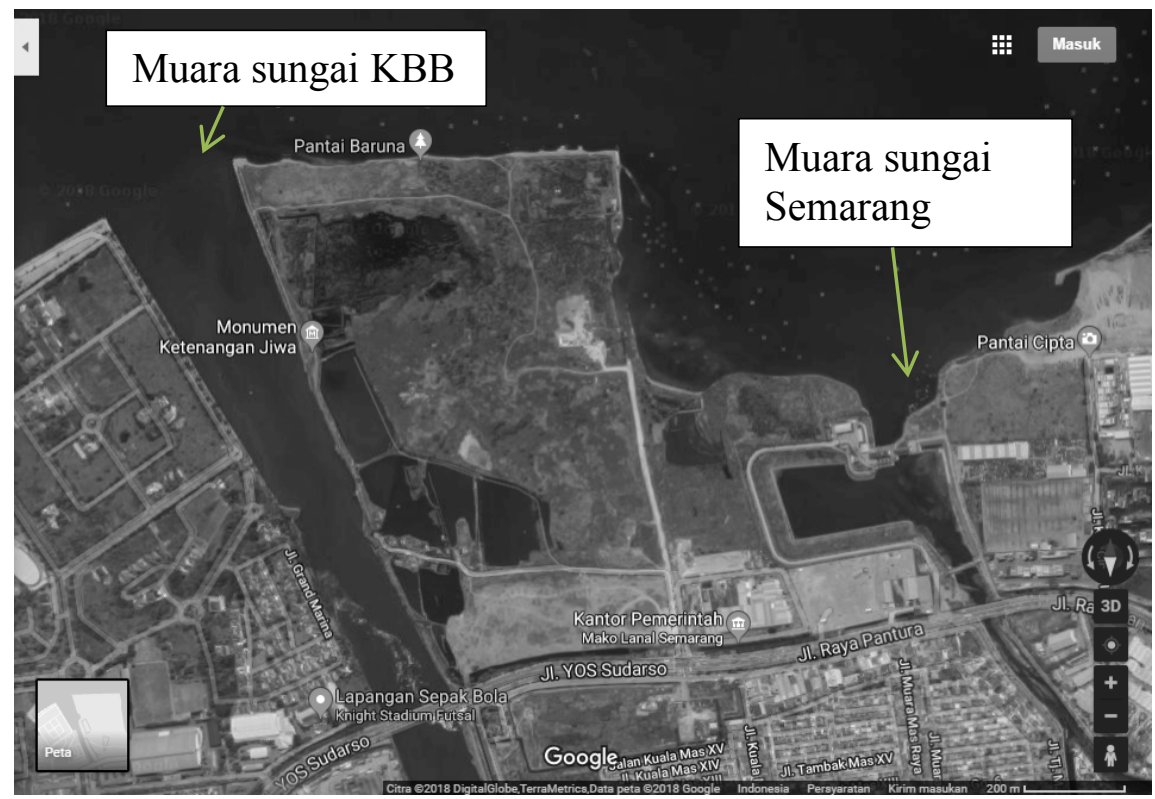

Gambar 2. Muara sungai KBB dan muara sungai Semarang 


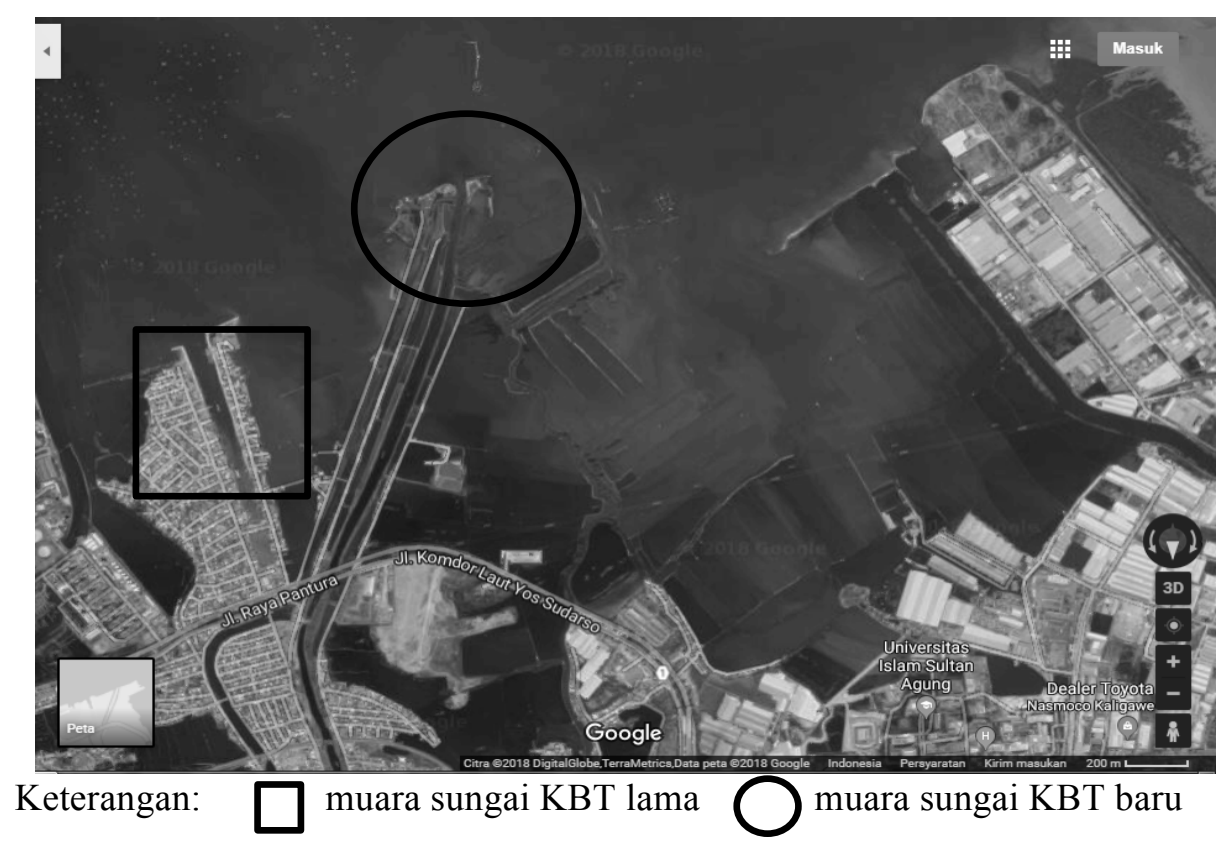

Gambar 3. Pembelokan muara sungai KBT 